\title{
Photoinhibition of photosynthesis is reduced by water flow in the reef-building coral Acropora digitifera
}

\author{
T. Nakamura ${ }^{1}$, R. van Woesik ${ }^{2, *}$, H. Yamasaki ${ }^{1}$ \\ ${ }^{1}$ Center of Molecular Biosciences, University of the Ryukyus, Senbaru 1, Nishihara, Okinawa 903-0213, Japan \\ ${ }^{2}$ Department of Biological Sciences, Florida Institute of Technology, 150 West University Boulevard, Melbourne, \\ Florida 32901-6988, USA
}

\begin{abstract}
While photosynthesis of symbiotic algae is essential for reef-building corals, excess irradiance inhibits photosynthesis through photoinhibition, which can lead to coral bleaching under elevated temperature conditions. Here we show that water flow reduces photoinhibition of in hospite endosymbionts in the coral Acropora digitifera. Diurnal monitoring of chlorophyll fluorescence, under 2 different flow regimes ( $<3$ and $20 \mathrm{~cm} \mathrm{~s}^{-1}$ flow rates) in an outdoor aquarium, showed reduced photoinhibition, but only under moderate flow conditions $\left(20 \mathrm{~cm} \mathrm{~s}^{-1}\right)$. Experimental (laboratory) measurements, on time scales ranging from minutes to hours, showed that flow-mediated reductions in photoinhibition occurred not by enhancing recovery of the damaged photosystem, but rather through inducing differential photodamage. Moreover, experiments involving sequential light oscillations $\left(500 / 20\right.$ and 1000/20 $\mu \mathrm{mol}$ photons $\left.\mathrm{m}^{-2} \mathrm{~s}^{-1}\right)$ at 3 flow regimes, $<3,10$, and $20 \mathrm{~cm} \mathrm{~s}^{-1}$, on a time scale ranging from hours to days, revealed water-velocity-dependent reductions of dynamic photoinhibition. These results, on time scales ranging from minutes to weeks, confirm that reduced water flow amplifies photodamage of algal photosynthesis under strong irradiance, which in turn affects coral tolerance to strong irradiance and temperature.
\end{abstract}

KEY WORDS: Coral bleaching $\cdot$ Photoinhibition $\cdot$ Water-flow rates $\cdot$ Passive diffusion

\section{INTRODUCTION}

In the last 3 decades mass coral bleaching events have damaged and, in many localities, caused longterm changes to coral communities (Glynn 1991, Goreau \& Hayes 1994, Wilkinson 1999, Goreau et al. 2000, Loya et al. 2001, Sheppard et al. 2002, Hughes et al. 2003). Although several environmental stressors cause corals to bleach, including reduced salinity (van Woesik et al. 1995), bacterial infections (Kushmaro et al. 1996), sedimentation (Philipp \& Fabricius 2003), and UV radiation (Brown et al. 1994, Shick et al. 1996), most recent bleaching events have been a consequence of high sea surface temperature in direct combination with high irradiance (Glynn 1993, 1996, Shick et al. 1996, Hoegh-Guldberg 1999).
While dependent on photosynthetically active radiation, corals and their symbionts are adversely affected by excessively strong irradiance, a phenomenon known as photoinhibition (Barber \& Andersson 1992, Aro et al. 1993, Osmond 1994, Jones et al. 1998, Warner et al. 1999), and recent studies have shown that photoinhibition is involved in coral bleaching (Lesser 1997, Jones \& Hoegh-Guldberg 2001, Warner et al. 2002). Shallow-water corals frequently suffer from continuous exposure to strong irradiance during low tide (Brown et al. 1994, 2000). However, such shallow reef environments also provide high water flow, inducing high mass transfer rates (Dennison \& Barnes 1988, Sebens et al. 2003). Several metabolic processes are affected by water-flow rates (Dennison \& Barnes 1988, Patterson 1992, Atkinson et al. 1994, Lesser et al. 
1994), which are assumed to be related to differential diffusion via mass-transfer-limited processes (Nakamura \& van Woesik 2001).

Water-flow rates also influence the degree to which corals can tolerate high temperatures and irradiance (Nakamura \& van Woesik 2001, Nakamura et al. 2003), yet the mechanisms associated with differential tolerance remain unclear. One possibility is that the external supply of carbon dioxide becomes insufficient to sustain algal photosynthesis under strong irradiance and high temperature (Weis et al. 1989), particularly when water-flow rates are low and diffusion is restricted. Alternatively, oxygen radicals that build up within corals during high temperatures and strong irradiance may damage adjoining tissue (Lesser 1997, Downs et al. 2002), which may become less concentrated in high-water-flow environments. While the mechanism(s) remain unknown, it is clear that increasing water-flow rates reduces bleaching susceptibility in branching corals (Nakamura \& van Woesik 2001). Here we test whether there is any down-regulation in photosystem II (PS II) activity of chloroplasts within symbiotic algae during acute light stress events that varies in accordance with water-flow rates in Acropora digitifera, and we examine whether photosystem recovery under dim light is directly affected by the water-flow regime. We undertook 3 different experiments. The 1st experiment, conducted in an outdoor aquarium, examined photosynthetic efficiency under naturally fluctuating irradiance and temperature with controlled water-flow rates. The 2 nd laboratory experiment examined hour-scale dynamic photoinhibition and recovery in accordance with 2 light and 2 flow treatments. The 3rd experiment was a novel sequential light-oscillation experiment that assessed whether differential photoinhibition is water-flow dependent. We demonstrate in all 3 cases that water-flow rates strongly influence levels of photoinhibition.

\section{MATERIALS AND METHODS}

Sample collection and acclimation. In early May 2002, we sampled $180(4.5$ to $5.0 \mathrm{~cm})$ branches from 32 Acropora digitifera coral colonies ( 5 to 6 branches per colony) from a shallow (1 $\mathrm{m}$ at low water spring) lagoon off Ginowan, Okinawa, Japan. Samples were taken from the central portion of each colony to obtain similar-shaped, vertical branches. They were immediately attached to polycarbonate screws using gel superglue (Alone-alpha, Toagosei, Japan). Nubbins were acclimated in an open-flow-through aquarium (length $200 \mathrm{~cm}$, width $100 \mathrm{~cm}$, depth $60 \mathrm{~cm}$ ) at Sesoko Station, Tropical Biosphere Research Center (University of the Ryukyus, Japan) for 3 mo. Using a neutral shade cloth we reduced irradiance to $\sim 500 \mu \mathrm{mol}$ photons $\mathrm{m}^{-2} \mathrm{~s}^{-1}$ at midday maximum (measured using the microphoton PAR sensor on a Diving-PAM fluorometer). The aquarium was aerated, and water flow was maintained at $\sim 3 \mathrm{~cm} \mathrm{~s}^{-1}$ with a submersible pump (REI-SEA RSD-40, Iwaki Pumps).

Open-aquarium experiments. For experimental manipulation, the coral samples were kept in Perspex miniflumes (length $140 \mathrm{~cm}$, width $10 \mathrm{~cm}$, height $10 \mathrm{~cm}$; water depth was kept constant at 5 to $6 \mathrm{~cm}$, similar to the method described by Atkinson \& Bilger 1992, Nakamura \& van Woesik 2001, Nakamura et al. 2003). These miniflumes were supported on concrete blocks within an open aquarium (length $200 \mathrm{~cm}$, width $150 \mathrm{~cm}$, depth $50 \mathrm{~cm}$ ) supplied with running seawater. All samples were suspended horizontally by mounting polyscrews on acrylic holders so that the fixed portions of the samples were exposed to sunlight. In the miniflumes the water-flow rates were generated and maintained at $20 \mathrm{~cm} \mathrm{~s}^{-1}$ and $<3 \mathrm{~cm} \mathrm{~s}^{-1}$ with submersible pumps (REI-SEA RSD-40).

During the period from August 7 to August 21, 2002, maximum quantum yield of PS II $\left(F_{\mathrm{v}} / F_{\mathrm{m}}\right)$ was measured for in hospite symbiotic algae in the Acropora digitifera samples exposed to different flow treatments $(n=5$ per treatment). Irradiance levels were continuously monitored and averaged every 5 min using a data logger and a photon sensor (LI-COR, LI-193 SA, LI-1000). Simultaneously, StowAway data loggers (Tidbit, Onset) were deployed for each flow-treatment flume in order to record the water temperature variability over the experimental period; loggers were calibrated before flume deployment.

Before the experiments began, initial samples $(n=5)$ were extracted and frozen at $-20^{\circ} \mathrm{C}$ for analysis of zooxanthella density and chlorophyll content. Upon termination of the experiments, all samples $(n=5$ per treatment; total $\mathrm{n}=10$ ) were immediately frozen and taken to the laboratory to determine zooxanthella density and chlorophyll content. For zooxanthella density counts, tissue was removed from skeletons with a WaterPik (Johannes \& Wiebe 1970) and centrifuged $\left(15000 \times g, 15 \mathrm{~min}, 10^{\circ} \mathrm{C}\right)$. The top clear layer was then discarded, and remaining zooxanthella pellets were resuspended in $10 \mathrm{ml}$ of filtered seawater. Centrifugation was repeated 3 times. Subsamples were then taken for hemocytometer counts. Only healthy looking zooxanthellae were counted (i.e. irregular-shaped cells were excluded) each time. Four replicates were taken from each WaterPik product. Coral surface area was estimated using the aluminum foil method (Marsh 1970). For chlorophyll extraction, $90 \%$ acetone was added to zooxanthella pellets after 3 repeated washing centrifugations; the samples were left in the dark at low temperature, 7 to $10^{\circ} \mathrm{C}$, for $48 \mathrm{~h}$. The extracted 
solution was centrifuged to exclude suspended matter prior to spectrophotometer measurements. Chlorophyll $a$ and $c_{2}$ concentrations were calculated using the equations described by Jeffrey \& Humphrey (1975).

To assess the PS II efficiency of the in hospite symbiotic algae, we applied chlorophyll fluorescence techniques (Schreiber et al. 1986) using a Diving-PAM fluorometer (Walz, Germany). The appropriate duration of dark adaptation was determined by measuring fluorescence after $1,3,5,10,15,20,30,45$, and $60 \mathrm{~min}$ of darkness. Minimum fluorescence $\left(F_{0}\right)$ was determined using $3 \mu$ s pulses of a light-emitting diode (measuring light, LED, peak emission at $650 \mathrm{~nm}$ ), and the maximum fluorescence $\left(F_{\mathrm{m}}\right)$ of each dark-adapted sample was measured by a $0.8 \mathrm{~s}$ saturation light pulse $\left(8000 \mu \mathrm{mol}\right.$ photons $\left.\mathrm{m}^{-2} \mathrm{~s}^{-1}\right) . F_{\mathrm{v}} / F_{\mathrm{m}}$, the ratio of variable fluorescence $\left(F_{\mathrm{v}}\right.$, where $\left.F_{\mathrm{v}}=F_{\mathrm{m}}-F_{0}\right)$ to $F_{\mathrm{m}}$ was determined for various dark-adapted periods ( $\mathrm{n}=4$ per period). Dark-adapted $F_{\mathrm{v}} / F_{\mathrm{m}}$ values increased exponentially in the first $15 \mathrm{~min}$ and then rapidly stabilized; therefore, we dark-adapted the experimental samples for $15 \mathrm{~min}$.

Dark-adapted $F_{\mathrm{v}} / F_{\mathrm{m}}$ is a measure of the maximum potential quantum yield of PS II (Demmig \& Bjorkman 1987 ), and the loss of $F_{\mathrm{v}} / F_{\mathrm{m}}$ is synonymous with photoinhibition of photosynthesis in response to strong irradiance (Franklin et al. 1992). Therefore, we used this parameter of photosynthesis to determine the degree of photoinhibition under strong irradiance. Fluorescence measurements were carried out from 05:00 to 21:00 h (measurements at: 05:00, 07:00, 09:00, 12:00, 15:00, 17:00, 19:00, and 21:00 h) after 15 min dark adaptation. To monitor the detailed diurnal dynamics of $F_{\mathrm{v}} / F_{\mathrm{m}}$, separate groups of coral samples (n $=5$ per treatment) were measured every hour for the 1st day of the experimental period. The sun rose around 06:10 h and set around 19:10 h during the experimental period.

Laboratory experiments. All the laboratory experiments were conducted at $28^{\circ} \mathrm{C}$ using a thermominder system (SM-05R, TAITEC). Samples were chosen randomly and kept horizontally suspended within the miniflumes (length $100 \mathrm{~cm}$, width $10 \mathrm{~cm}$, height $15 \mathrm{~cm}$; water depth was kept constant at $10 \mathrm{~cm}$, according to the method of Atkinson \& Bilger [1992] with slight modifications). In the 1st laboratory experiment, we examined the effect of water-flow treatments: $<3 \mathrm{~cm}$ $\mathrm{s}^{-1}$ and $20 \mathrm{~cm} \mathrm{~s}^{-1}$, referred to as still and flow, respectively. Water motion for the still treatment was generated simply using the thermominder and aeration. Water flow for the (flow) treatments was generated using submersible mini water pumps (WISE-MICRO, Suisou Pumps) and thermominders and aerators. Samples ( $\mathrm{n}=12$ per treatment) were exposed to 2 light treatments, (1) $500 \mu \mathrm{mol}$ photons $\mathrm{m}^{-2} \mathrm{~s}^{-1}$ and (2) $1000 \mu \mathrm{mol}$ photons $\mathrm{m}^{-2} \mathrm{~s}^{-1}$, using optical tubes connected to a cool-light system and a UV filter (NPI, Picl-nex; projection lamp $150 \mathrm{~W}$, PHILLIPS, USA) for $1 \mathrm{~h}$. To examine photosystem recovery, $1 \mathrm{~h}$ of high irradiation was followed by non-photodamaging $20 \mu \mathrm{mol}$ photons $\mathrm{m}^{-2} \mathrm{~s}^{-1}$ for the next hour. $F_{\mathrm{v}} / F_{\mathrm{m}}$ was measured after every $30 \mathrm{~min}$ of light exposure followed by $15 \mathrm{~min}$ of dark adaptation. The 2 nd experiment assessed the flow effect on recovery of equally damaged samples. Samples ( $\mathrm{n}=12$ per treatment) were preexposed to $1000 \mu \mathrm{mol}$ photons $\mathrm{m}^{-2} \mathrm{~s}^{-1}$ for $1 \mathrm{~h}$ under still conditions before the measurements were taken, then placed in either flow or still conditions for the next hour under dim light to assess recovery. Flume water was changed slowly $(500 \mathrm{ml} / \mathrm{min})$ with preheated $\left(28^{\circ} \mathrm{C}\right)$ filtered seawater every $30 \mathrm{~min}$.

In the 3rd experiment, photodamage and recovery (dark-adapted $F_{\mathrm{v}} / F_{\mathrm{m}}$ ) were investigated over $2 \mathrm{~h}$ intervals at $28^{\circ} \mathrm{C}$. We maintained 3 flow treatment velocities: $<3,10$, and $20 \mathrm{~cm} \mathrm{~s}^{-1}$ referred to as still, medium, and high, respectively. We assessed differential effects of water flow by exposing samples to $2 \mathrm{~h}$ of $500 \mu \mathrm{mol}$ photons $\mathrm{m}^{-2} \mathrm{~s}^{-1}$ light (damage phase) followed by $2 \mathrm{~h}$ of $20 \mu \mathrm{mol}$ photons $\mathrm{m}^{-2} \mathrm{~s}^{-1}$ (recovery phase) for 10 cycles $(40 \mathrm{~h}) . F_{\mathrm{v}} / F_{\mathrm{m}}$ values were measured every $2 \mathrm{~h}$ (between damage and recovery phases), followed by $15 \mathrm{~min}$ of dark adaptation throughout the experimental period. We undertook similar experiments under $2 \mathrm{~h}$ of $1000 \mu \mathrm{mol}$ photons $\mathrm{m}^{-2} \mathrm{~s}^{-1}$, followed by $2 \mathrm{~h}$ under $20 \mu \mathrm{mol}$ photons $\mathrm{m}^{-2} \mathrm{~s}^{-1}$ (recovery phase), for 6 cycles $(24 \mathrm{~h})$. Flume water was changed slowly (500 $\mathrm{ml} \mathrm{min}^{-1}$ ) with preheated $\left(28^{\circ} \mathrm{C}\right)$ filtered seawater every hour.

Data analysis. For the results of the outdoor experiments, a nested ANOVA with repeated measures was used to compare the dark-adapted quantum yield of PS II $\left(F_{\mathrm{v}} / F_{\mathrm{m}}\right)$ between the flow and still treatments. All data were assessed for normality and homogeneity of variances prior to testing. Transformations were applied where appropriate, and violations of ANOVA assumptions were reevaluated. Two-tailed $t$-tests were used to assess the differences in experimental treatments relating to the dependent variables chlorophyll content and zooxanthella density and differential water-flow treatment (comparing initial samples, with still, at $<3 \mathrm{~cm} \mathrm{~s}^{-1}$ and flow, at $20 \mathrm{~cm} \mathrm{~s}^{-1}$ treatments).

\section{RESULTS}

\section{Outdoor experiments}

During the course of the experiment, as expected, and as may occur on shallow reefs, the water temperature closely followed irradiance intensity (Fig. 1A). PS II efficiencies inversely tracked photosynthetically active radiation (PAR), at least for the first day of the 

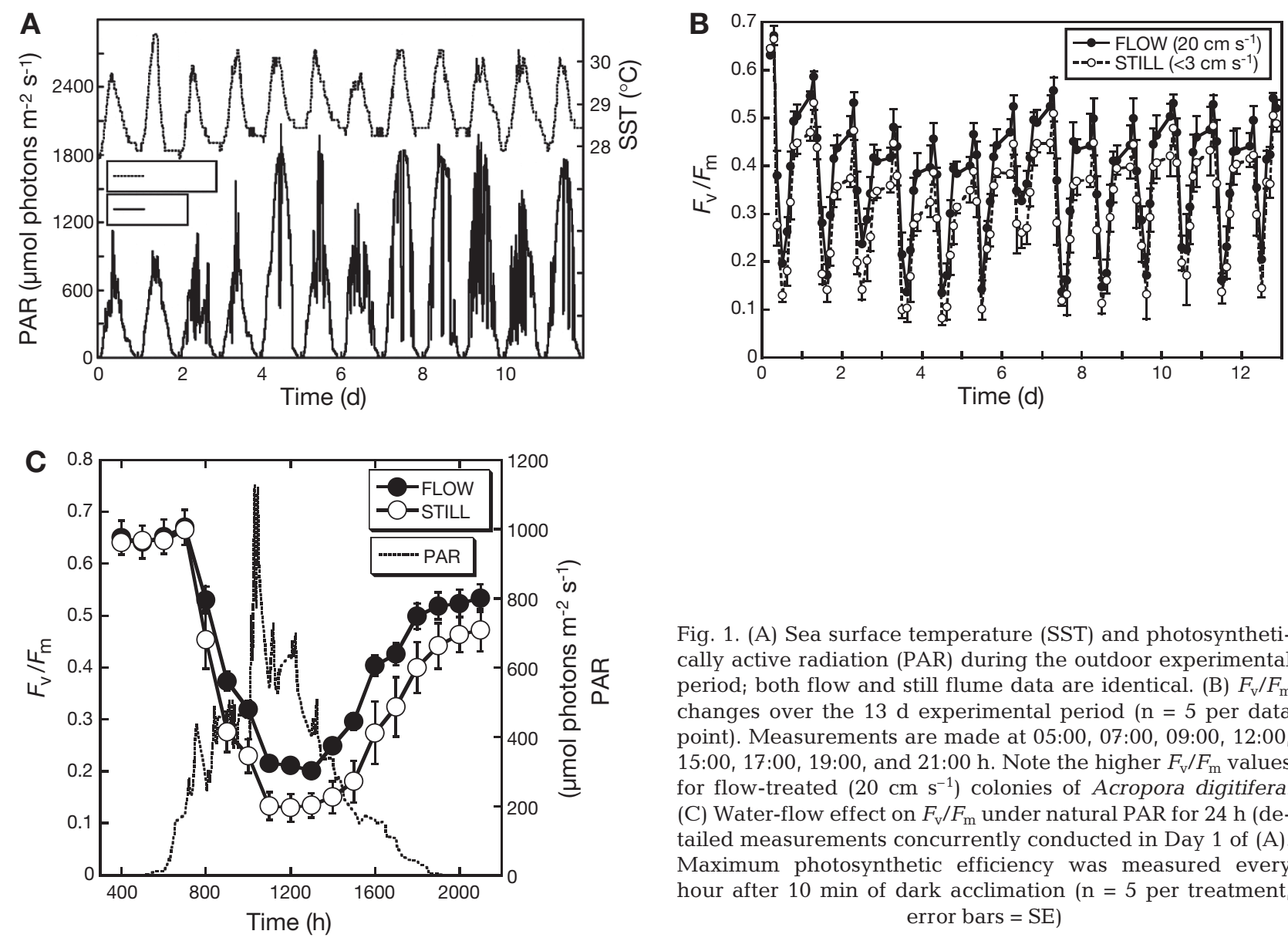

Fig. 1. (A) Sea surface temperature (SST) and photosynthetically active radiation (PAR) during the outdoor experimental period; both flow and still flume data are identical. (B) $F_{\mathrm{v}} / F_{\mathrm{m}}$ changes over the $13 \mathrm{~d}$ experimental period $(\mathrm{n}=5$ per data point). Measurements are made at 05:00, 07:00, 09:00, 12:00, $15: 00,17: 00,19: 00$, and 21:00 h. Note the higher $F_{\mathrm{v}} / F_{\mathrm{m}}$ values for flow-treated $\left(20 \mathrm{~cm} \mathrm{~s}^{-1}\right)$ colonies of Acropora digitifera. (C) Water-flow effect on $F_{\mathrm{v}} / F_{\mathrm{m}}$ under natural PAR for $24 \mathrm{~h}$ (detailed measurements concurrently conducted in Day 1 of (A). Maximum photosynthetic efficiency was measured every hour after 10 min of dark acclimation $(\mathrm{n}=5$ per treatment, error bars $=\mathrm{SE}$ )

experiment where the SST stayed lower than $30^{\circ} \mathrm{C}$ (Fig. 1B,C, $F_{\mathrm{v}} / F_{\mathrm{m}}=-0.0006 \times \mathrm{PAR}+0.5575$, total $\mathrm{n}=$ 180 , correlation $r^{2}=0.598$ for Fig. $1 C$ ). It is noteworthy that the water temperatures did not differ significantly between water-flow treatments throughout the experimental period (Table 1). The maximum potential quantum yield of PS II $\left(F_{\mathrm{v}} / F_{\mathrm{m}}\right)$ under both flow treatments showed a gradual decline after the 1st day following an increase in irradiance and temperature (Fig. 1). The most notable result was the significantly reduced photoinhibition under increased water flow ( $\mathrm{p}<0.045$, nested repeated measures ANOVA, Table 2$) ; F_{\mathrm{v}} / F_{\mathrm{m}}$, became $\sim 10 \%$ higher under moderate flow compared with low flow treatment (Fig. 1C).

Table 1. Descriptive summary statistics on water temperature $\left({ }^{\circ} \mathrm{C}\right)$ for both flow and still treatments during the $13 \mathrm{~d}$ experimental period

\begin{tabular}{|lccccc|}
\hline Treatment & Mean & SD & $\mathrm{n}$ & Min. & Max. \\
\hline Flow & 28.838 & 0.717 & 2030 & 27.58 & 30.69 \\
Still & 28.803 & 0.718 & 2030 & 27.54 & 30.65 \\
\hline
\end{tabular}

There was no statistical difference in (healthy-shaped, pigmented) zooxanthella density between the 2 flow treatments ( $t$-test, $\mathrm{p}>0.71$, Fig. 2 ). Both treatments showed statistically significant reductions from the initial samples (by 1/6, $t$-tests, $p<0.001$ for both, Fig. 2). Chlorophyll concentrations per tissue area showed

Table 2. Acropora digitifera. Nested repeated measures analysis of variance (ANOVA) assessing the dark-acclimated quantum yield of PS II $\left(F_{\mathrm{v}} / F_{\mathrm{m}}\right)$ for flow treatments over $13 \mathrm{~d}$

\begin{tabular}{|c|c|c|c|c|}
\hline & df & MS & $F$ & p-level \\
\hline \multicolumn{5}{|c|}{ Between subjects } \\
\hline Flow (F) & 1 & 0.9461 & \multirow{2}{*}{5.6307} & \multirow[t]{2}{*}{0.0450} \\
\hline Error & 8 & 0.168 & & \\
\hline \multicolumn{5}{|c|}{ Within subjects } \\
\hline Day (D) & 12 & 0.1157 & \multirow{2}{*}{58.3142} & \multirow[t]{2}{*}{0.0001} \\
\hline Error & 96 & 0.002 & & \\
\hline Hour (H) & 91 & 0.1523 & \multirow{2}{*}{166.8164} & \multirow[t]{2}{*}{0.0001} \\
\hline Error & 728 & 0.001 & & \\
\hline $\mathrm{F} \times \mathrm{D}$ & 12 & 0.0037 & \multirow[t]{2}{*}{1.8619} & \multirow[t]{2}{*}{0.0489} \\
\hline Error & 96 & 0.002 & & \\
\hline $\mathrm{F} \times \mathrm{H}$ & 91 & 0.0014 & \multirow[t]{2}{*}{1.5568} & \multirow{2}{*}{0.0013} \\
\hline Error & 728 & 0.001 & & \\
\hline
\end{tabular}




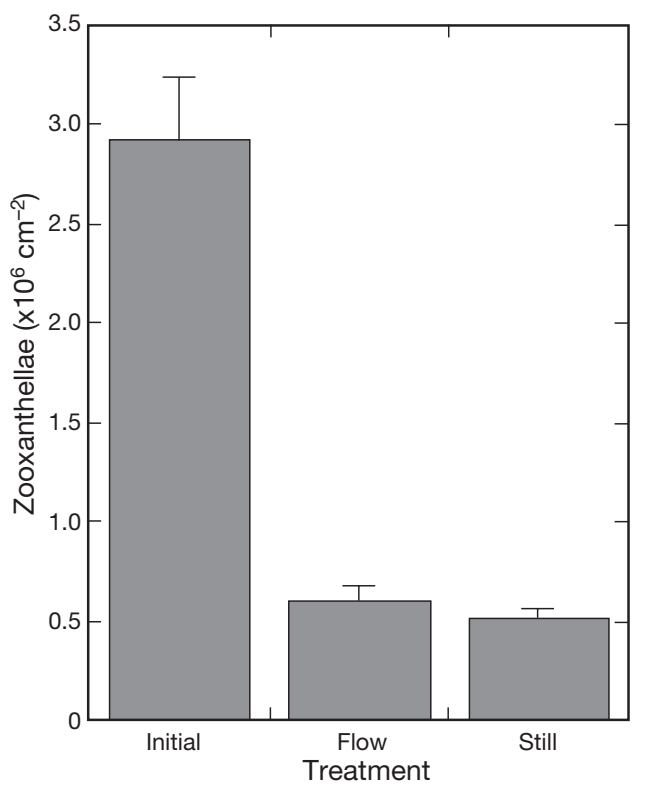

Fig. 2. Acropora digitifera. Number of zooxanthellae per unit coral tissue area at onset of experiment (initial) compared with after $13 \mathrm{~d}$ of flow $\left(20 \mathrm{~cm} \mathrm{~s}^{-1}\right)$ and still $\left(<3 \mathrm{~cm} \mathrm{~s}^{-1}\right)$ treatments ( $\mathrm{n}=5$ per treatment)

significant differences between the flow $\left(20 \mathrm{~cm} \mathrm{~s}^{-1}\right)$ and still $\left(<3 \mathrm{~cm} \mathrm{~s}^{-1}\right)$ treatments $(t$-test, $\mathrm{p}<0.003)$, with moderate flow inducing higher chlorophyll per zooxanthella concentrations than both the still and initial concentrations $(p<0.0092$ for Flow $\times$ Still, $p<0.00540$ for Flow $\times$ Initial, Fig. 3).

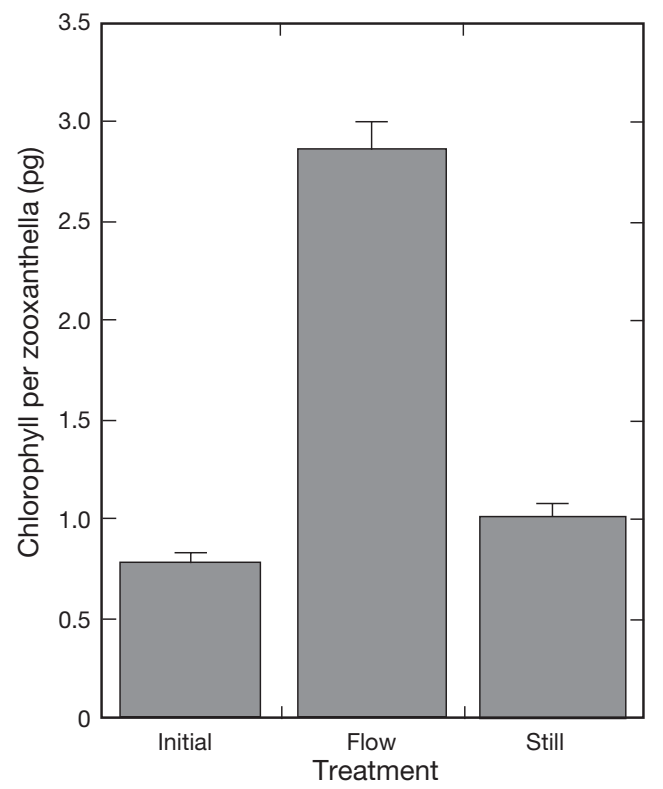

Fig. 3. Chlorophyll content per single algal cell (mean + SE) at onset of experiment (initial) compared with after $13 \mathrm{~d}$ of flow $\left(20 \mathrm{~cm} \mathrm{~s}^{-1}\right)$ and still $\left(<3 \mathrm{~cm} \mathrm{~s}^{-1}\right)$ treatments $(\mathrm{n}=5$ per treatment)

\section{Laboratory experiments}

Flow-dependent $F_{\mathrm{v}} / F_{\mathrm{m}}$ differences appeared only after 60 min under the $500 \mu \mathrm{mol}$ photons $\mathrm{m}^{-2} \mathrm{~s}^{-1}$ treatments; higher $F_{\mathrm{v}} / F_{\mathrm{m}}$ values were observed for coral samples in $20 \mathrm{~cm} \mathrm{~s}^{-1}$ water flow compared with colonies
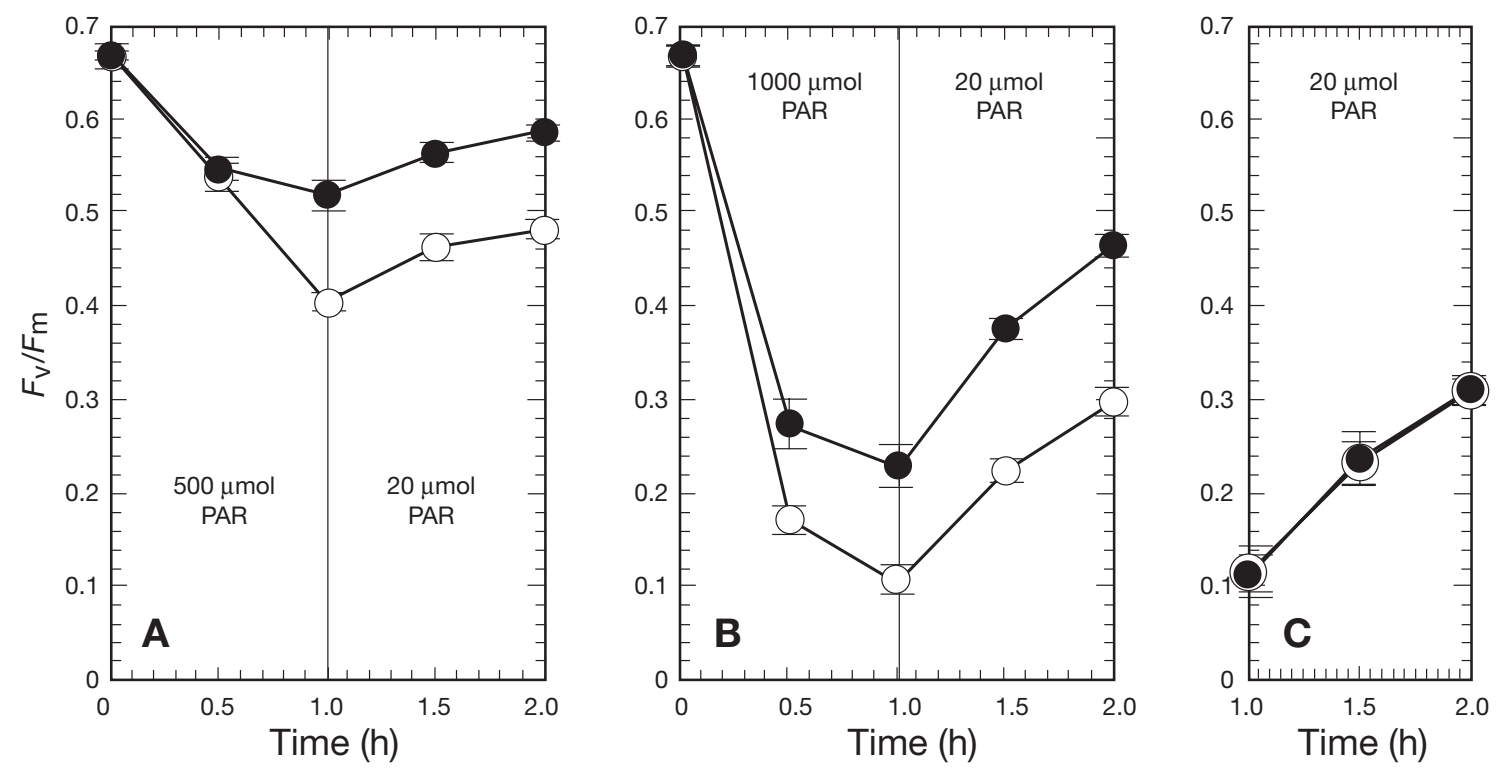

Fig. 4. Acropora digitifera. $F_{\mathrm{v}} / F_{\mathrm{m}}$ changes in symbiotic algae under flow $\left(\bullet, 20 \mathrm{~cm} \mathrm{~s}^{-1}\right)$ and still $\left(\mathrm{O},<3 \mathrm{~cm} \mathrm{~s}^{-1}\right) \mathrm{conditions}$ at $28^{\circ} \mathrm{C}$. Corals were exposed to (A) $500 \mu \mathrm{mol}$ photons $\mathrm{m}^{-2} \mathrm{~s}^{-1}$ and (B) $1000 \mu \mathrm{mol}$ photons $\mathrm{m}^{-2} \mathrm{~s}^{-1}$ for the first hour, then placed under $20 \mu \mathrm{mol}$ photons $\mathrm{m}^{-2} \mathrm{~s}^{-1}$ for the next hour to recover $(\mathrm{n}=12$ per data point). (C) Recovery under flow and still treatments in corals ( $\mathrm{n}=12$ per treatment) that were exposed to $1000 \mu \mathrm{mol}$ photons $\mathrm{m}^{-2} \mathrm{~s}^{-1}$ light under still conditions for $1 \mathrm{~h}$ prior to the recovery measurements. Error bars = SE 

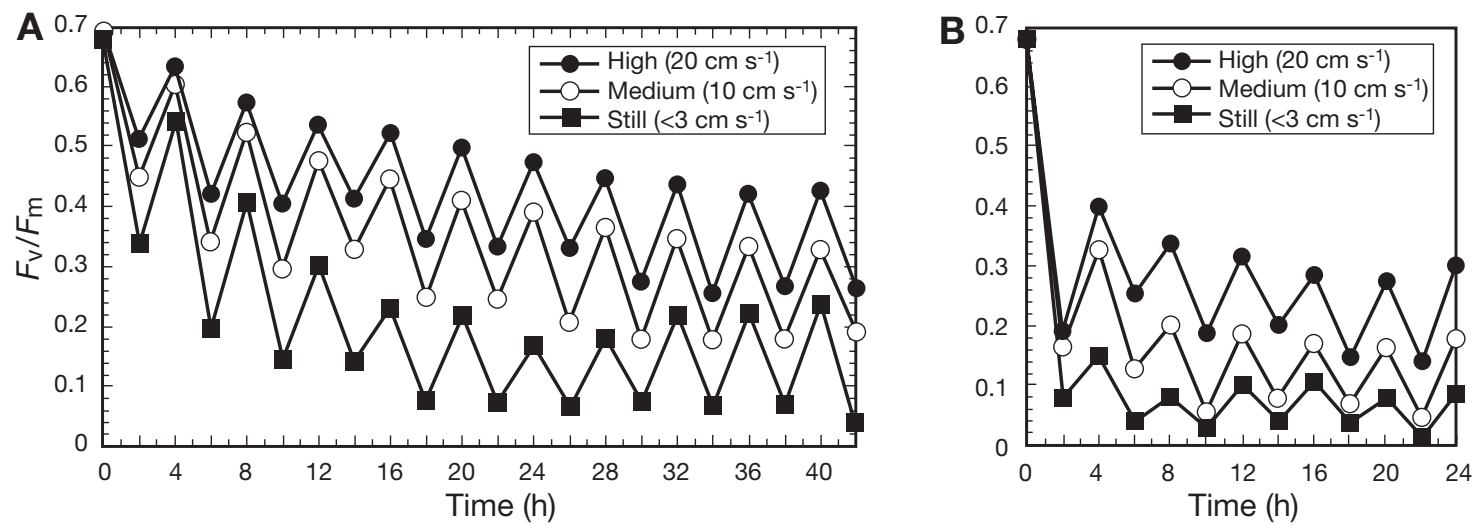

Fig. 5. Acropora digitifera. $F_{\mathrm{v}} / F_{\mathrm{m}}$ changes in symbiotic algae under high $\left(20 \mathrm{~cm} \mathrm{~s}^{-1}\right)$, medium $\left(10 \mathrm{~cm} \mathrm{~s}^{-1}\right)$, and still $\left(<3 \mathrm{~cm} \mathrm{~s}^{-1}\right)$ flow conditions. Corals were exposed to (A) $500 \mu \mathrm{mol}$ photons $\mathrm{m}^{-2} \mathrm{~s}^{-1}$ and (B) $1000 \mu \mathrm{mol}$ photons $\mathrm{m}^{-2} \mathrm{~s}^{-1}$ for $2 \mathrm{~h}$ followed by $2 \mathrm{~h}$ of $20 \mu \mathrm{mol}$ photons $\mathrm{m}^{-2} \mathrm{~s}^{-1}$. Sequential light oscillations were conducted over 10 cycles $\left(\mathrm{A}_{;} \mathrm{n}=12\right.$ per data point; averaged SE for max., low, and min. is $0.0142,0.0154$, and 0.0149 , respectively) and 6 cycles ( $\mathrm{B} ; \mathrm{n}=12$ per data point; averaged SE for max., low, and min. $=0.0223,0.0156$, and 0.0153 , respectively)

subjected to $<3 \mathrm{~cm} \mathrm{~s}^{-1}$ (Fig. 4A). As expected, photoinhibition was more severe under $1000 \mu \mathrm{mol}$ photons $\mathrm{m}^{-2}$ $\mathrm{s}^{-1}$ treatments compared with $500 \mu \mathrm{mol}$ photons $\mathrm{m}^{-2} \mathrm{~s}^{-1}$ treatments, but the rate of $F_{\mathrm{v}} / F_{\mathrm{m}}$ decline was less at $20 \mathrm{~cm} \mathrm{~s}^{-1}\left(0.0131 \mathrm{~min}^{-1}\right)$ compared with $<3 \mathrm{~cm} \mathrm{~s}^{-1}$ $\left(0.0165 \mathrm{~min}^{-1}\right)$ in the first $30 \mathrm{~min}$ (Fig. 4B). A $1 \mathrm{~h} \mathrm{ex-}$ posure to $1000 \mu \mathrm{mol}$ photons $\mathrm{m}^{-2} \mathrm{~s}^{-1}$ reduced $F_{\mathrm{v}} / F_{\mathrm{m}}$ to $0.115 \pm 0.008(\mathrm{n}=24)$. The net recovery rates, at least for the first hour, showed no differences between the flow $\left(20 \mathrm{~cm} \mathrm{~s}^{-1}\right)$ and still $\left(<3 \mathrm{~cm} \mathrm{~s}^{-1}\right)$ conditions (Fig. $\left.4 \mathrm{C}\right)$. The $F_{\mathrm{v}} / F_{\mathrm{m}}$ values after a $1 \mathrm{~h}$ recovery phase was $0.309 \pm$

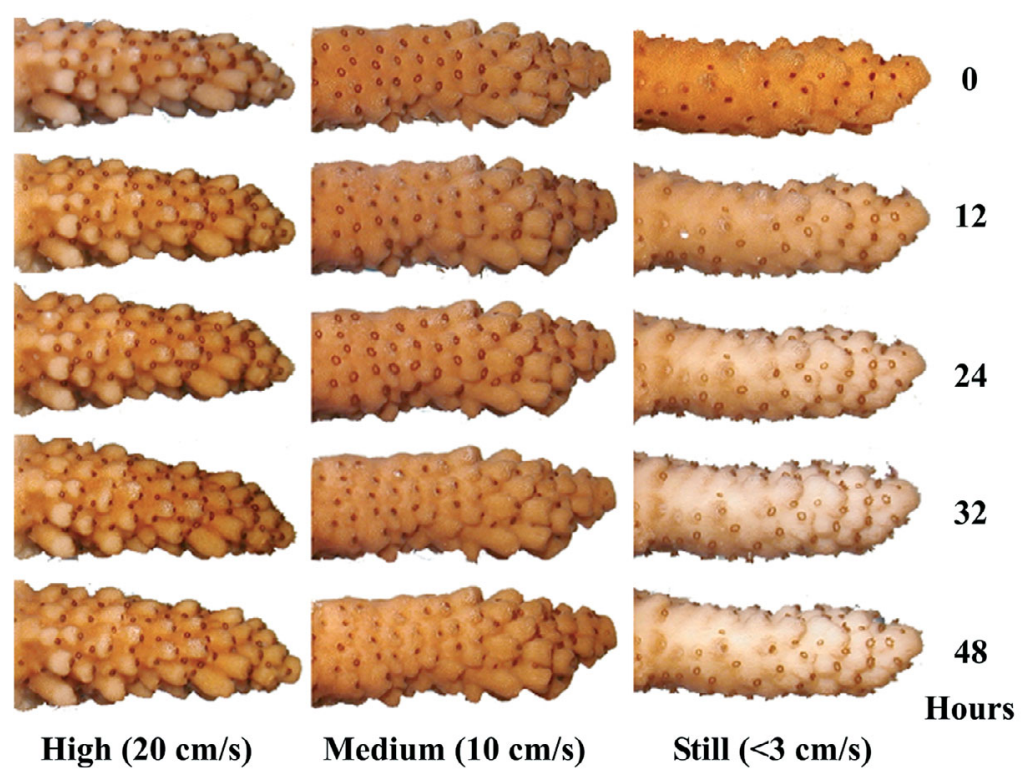

Fig. 6. Acropora digitifera. Representative changes in colony coloration among 3 flow treatments, under $500 \mu \mathrm{mol}$ photons $\mathrm{m}^{-2} \mathrm{~s}^{-1}$ : high $\left(20 \mathrm{~cm} \mathrm{~s}^{-1}\right)$, medium $\left(10 \mathrm{~cm} \mathrm{~s}^{-1}\right)$, and still $\left(<3 \mathrm{~cm} \mathrm{~s}^{-1}\right)$ flow treatments (columns, left to right) for 0 (initial), 12, 24, 32, and $42 \mathrm{~h}$ (rows, top to bottom)
0.008 and $0.310 \pm 0.009$ for flow and still treatments, respectively ( $\mathrm{n}=12$ per treatment).

Under sequential exposure to $500 \mu \mathrm{mol}$ photons $\mathrm{m}^{-2}$ $\mathrm{s}^{-1}$ followed by $20 \mu \mathrm{mol}$ photons $\mathrm{m}^{-2} \mathrm{~s}^{-1}$ of dim light, all (flow) treatments showed that gradual declines in PS II efficiency were a consequence of higher rates of photoinhibition relative to recovery. Yet PS II efficiency was highly dependent on flow rates, with higher flow rates showing higher $F_{\mathrm{v}} / F_{\mathrm{m}}$ ratios (Fig. 5A). Notably, there was less photoinhibition in the second $24 \mathrm{~h}$ (sequential light oscillation) period compared with the first $24 \mathrm{~h}$ period (at $500 \mu \mathrm{mol}$ photons $\mathrm{m}^{-2} \mathrm{~s}^{-1}$ ), although the recovery rate from photoinhibition (during the $20 \mu \mathrm{mol}$ photons $\mathrm{m}^{-2} \mathrm{~s}^{-1}$ periods) was similar over time for all treatments (Fig. 5A). Similar results were obtained in $1000 \mu \mathrm{mol}$ photons $\mathrm{m}^{-2} \mathrm{~s}^{-1}$ treatments, but photoinhibition was greater; $F_{\mathrm{v}} / F_{\mathrm{m}}$ was reduced to below $50 \%$ within the first $2 \mathrm{~h}$ of exposure (with decline rates of $0.0041,0.0043$, and $0.0050 \mathrm{~min}^{-1}$ for high, medium, and still treatments, respectively). Only colonies in high-flow treatments $\left(20 \mathrm{~cm} \mathrm{~s}^{-1}\right)$ regained $25 \%$ of their initial PS II efficiency $\left(F_{\mathrm{v}} / F_{\mathrm{m}}\right)$ after every recovery phase (Fig. 5B). Visible pigment loss occurred particularly under still $\left(<3 \mathrm{~cm} \mathrm{~s}^{-1}\right)$ conditions after $48 \mathrm{~h}$ of sequential 500/20 $\mu \mathrm{mol}$ photons $\mathrm{m}^{-2} \mathrm{~s}^{-1}$ oscillations (Fig. 6). Colonies bleached in both $10 \mathrm{~cm} \mathrm{~s}^{-1}$ and $<3 \mathrm{~cm} \mathrm{~s}^{-1}$ under $1000 \mu \mathrm{mol}$ photons $\mathrm{m}^{-2} \mathrm{~s}^{-1}$ exposure (not shown), with the severity of photoinhibition in agreement with the degree of visible pigment loss. 


\section{DISCUSSION}

There is a clear reciprocity between temperature and irradiance, an increase in irradiance of $250 \mu \mathrm{mol}$ photons $\mathrm{m}^{-2} \mathrm{~s}^{-1}$ can induce the same effect as a $1^{\circ} \mathrm{C}$ rise in temperature (Takahashi et al. 2004). The dynamics of water flow may be equally important in explaining some patterns of bleaching and postbleaching recovery. Recent experimental evidence has shown that the prevention of and rapid recovery from bleaching is enhanced by water flow. This suggests that masstransfer-limited processes are clearly involved in coral bleaching (Nakamura \& van Woesik 2001, Nakamura et al. 2003). In the present study we show that the rates of down-regulation in PS II activity, during acute irradiance stress, are directly affected by water-flow rates. An increase in water flow led to a reduction in photoinhibition, which appeared to be independent of time scale (from minutes to weeks, Figs. 1, 4, \& 5). These results agree with several previous studies that investigated the effects of water flow on photosynthetic activity (Dennison \& Barnes 1988, Patterson et al. 1991, Lesser et al. 1994). Interestingly, on the scale of hours, moderate water flow reduced the level of photoinhibition by reducing the damaging process, but not by enhancing recovery of the damaged photosystem. Photoprotective dissipation of excess excitation energy through the cycling of xanthophyll pigments plays a major role in the down-regulation of PS II (Brown et al. 1999). However, the effects of water flow on the xanthophyll cycle (i.e. total pool size, turnover rate, and functional efficiency) under the influences of stressful temperature and irradiance conditions are not well known. We may consider that water flow increases the efficiency of xanthophyll cycling in the excess-energydissipation process in zooxanthella chloroplasts.

Research has shown that coral physiology is regulated by uptake processes (Atkinson \& Bilger 1992, Thomas \& Atkinson 1997). Increased water flow has also been reported to increase coral survival (Jokiel 1978), rates of photosynthesis (Lesser et al. 1994), calcification (Dennison \& Barnes 1988), phosphate uptake (Atkinson et al. 1994), and the generation of UV protective compounds (Kuffner 2001, 2002). Clearly, thick boundary layers form around corals under limited flow (Patterson \& Sebens 1989, Bilger \& Atkinson 1992), which may exacerbate photoinhibition because of insufficient mass transfer. Several possible steps explain the connection between the reduced waterflow rates and high coral mortality (Fig. 7). What remains unclear, at least at the initial onset of dysfunction, is which molecules actually become limiting and dependent on flow rates. One possibility is that the external supply of carbon becomes insufficient to maintain photosynthesis under stress induced by high irradiance and high temperature (Weis et al. 1989), just as the photosynthetic-activity and carbon-uptake pathways are regulated by external carbon source $\left(\mathrm{CO}_{2}\right.$ and $\left.\mathrm{HCO}_{3}^{-}\right)$concentrations for phytoplankton (Tortell et al. 2000).

Alternatively, passive diffusion of oxygen radicals that build up within corals during high temperatures and irradiance are retained and damage adjoining tissue (Lesser 1997). Photoinhibition involves inactivation of the photosynthetic apparatus through the production of reactive oxygen species (ROS) such as superoxides (Asada 1999). Photoinhibition can depend solely on the intensity and duration of irradiance (Fig. 4). Excessive irradiance causes the overproduction of harmful ROS that in turn damage the photosynthetic apparatus (Asada 1999, Downs et al. 2002). Lightdependent ROS production occurs in chloroplasts, involving several possible pathways in both PS I and PS II (Badger 1985, Richter et al. 1990, Tjus et al. 2001), where the Mehler reaction (Mehler 1951) generates hydrogen peroxide $\left(\mathrm{H}_{2} \mathrm{O}_{2}\right)$ from superoxides (Downs et al. 2002). Consequently, highly permeable $\mathrm{H}_{2} \mathrm{O}_{2}$ would be removed efficiently by increasing mass transfer rates, from zooxanthellae to the surrounding water mass via the host cells. In this case, the reduction (simply by removal or detoxification) of harmful ROS molecules may become a crucial process for sustainable photosynthesis. Suppression of photoinhibition in the flow-treated Acropora digitifera may be explained, in part, by more rapid diffusion through the corals' boundary layers, yet such experiments need to be undertaken. In other words, diffusion limitation may enhance photoinhibition, and sustainable photosynthesis requires that irreversible photodamage to the photosynthetic apparatus be minimized.

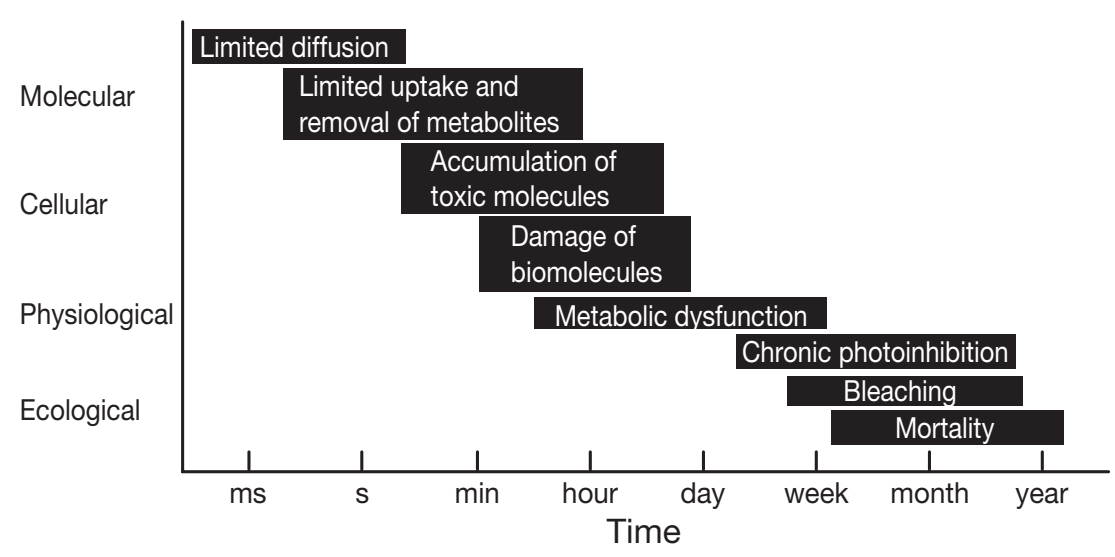

Fig. 7. Hypothetical steps leading to coral mortality, initiated in low-flow environments 
Aro et al. (1993) reviewed the literature and suggested that damaged photosystems require light energy to repair damaged protein through de novo synthesis. Although damaging and recovery processes of PS II occur simultaneously under light exposure, irreversible damage to photosystems may occur when the rate of damage to the photosynthetic apparatus exceeds the rate of recovery. This may explain why the highest $F_{\mathrm{v}} / F_{\mathrm{m}}$ in the evening was often not as high as $F_{\mathrm{v}} / F_{\mathrm{m}}$ in the morning at 07:00 $\mathrm{h}$, when irradiance was sufficient to induce light-dependent recovery of the damaged photosystem. When little recovery occurs under dim irradiance, further damage occurs upon exposure to high irradiance (Warner et al. 1999, Jones \& Hoegh-Guldberg 2001). The result of continuous stress, which is the fraction of nonfunctional photosystems over total photosystems, becomes larger and leads to chronic damage to the photosystems.

To maintain adequate levels of photosynthesis, damage must be reduced or repaired. Warner et al. (1999) and Takahashi et al. (2004) showed that inhibition of PS II protein repair leads to heat-dependent photoinhibition; therefore, high temperature tolerance is a consequence of high rates of photosystem repair relative to photodamage rather than simply a response of differential degrees of damage. However, when net damage is reduced, corals may sustain adequate levels of photosynthesis even under the temperature-dependent inhibition of photosystem recovery.

The sequential light-oscillation experiments, which repeatedly overstimulated and released the photocenters within chloroplasts, showed a consistent and positive relationship between reduced photoinhibition and water-flow rates. Yet the relationship is dynamic and far from linear and accumulative (Fig. 5). The coral samples in these experiments followed nonlinear functions over time, and interesting acclimative responses occurred even after just $24 \mathrm{~h}$. This requires further investigation. While there were relationships between the severity of photoinhibition and the degree of pigment loss, there were also relationships among limited flow, photoinhibition, and pigment loss. Although samples in both flow and still treatments had reduced zooxanthella populations (Fig. 2), the flow-treated samples kept the chlorophyll content per tissue area at a higher level compared with the still-treated samples (data not shown). In fact, a large proportion of irregular-shaped zooxanthellae (shrunk) were found in flowtreated colonies and excluded from the counts; our strict (i.e. conservative) counting method may have led to the underestimation of zooxanthella populations in flow-treated samples.

In conclusion, in an earlier study (Nakamura \& van Woesik 2001) we showed that flow-treated colonies had higher survival under stressful temperature and irradiance. In this study we examined the flow effects on photoinhibition, especially under stressful, bleaching conditions, i.e. under the influence of high irradiance and high temperature. We showed that bleaching is less likely in flow-affected environments because photoinhibition is reduced. While elevated sea surface temperatures induce large-scale coral bleaching events, the present study supports the hypothesis that flow-mediated enhancement of mass transfer reduces coral mortality by reducing photoinhibition at various time scales. In other words, while the mixing effect of high water flow may indeed reduce water temperatures, as shown by some recent studies, we suggest that enhanced shear stress across the coral tissue promotes passive diffusion across the boundary between the coral tissue and the ambient environment, thereby reducing stress through flow-mediated reduction of photoinhibition. However, which molecules become limiting or overproduced under low flow conditions is not fully understood and needs further investigation, especially for corals.

Acknowledgements. We thank Mr. Y. Nakano, S. Nakamura, and the faculties of Sesoko T.B.R.C., University of the Ryukyus, Japan. This work was supported by a grant-in-aid for JSPS fellows to T.N. and by the 21st century COE program of the University of the Ryukyus from the Ministry of Education, Culture, Sports, Science and Technology, Japan.

\section{LITERATURE CITED}

Aro EM, Virgin I, Andersson B (1993) Photoinhibition of Photosystem II. Inactivation, protein damage and turnover. Biochem Biophys Acta 1143:113-134

Asada K (1999) The water-water cycle in chloroplasts: scavenging of active oxygens and dissipation of excess photons. Annu Rev Plant Physiol Plant Mol Biol 50:601-639

Atkinson MJ, Bilger RW (1992) Effects of water velocity in phosphate uptake in coral reef-flat communities. Limnol Oceanogr 37 (2):273-279

Atkinson MJ, Kolter E, Newton P (1994) Effects of water velocity on respiration, calcification, and ammonium uptake of a Porites compressa community. Pac Sci 48: 296-303

Badger MR (1985) Photosynthetic oxygen exchange. Annu Rev Plant Physiol 36:27-53

Barber J, Andersson B (1992) Too much of a good thing: light can be bad for photosynthesis. Trends Biochem Sci 17: $61-66$

Bilger RW, Atkinson MJ (1992) Anomalous mass transfer of phosphate on coral reefs. Limnol Oceanogr 37:261-272

Brown BE, Dunne RP, Scoffin TP, Le Tissier MDA (1994) Solar damage in intertidal corals. Coral Reefs 105:219-230

Brown BE, Ambarsari I, Warner ME, Fitt WK, Dunne RP, Gibb SW, Cummings DG (1999) Diurnal changes in photochemical efficiency and xanthophyll concentrations in shallow water reef corals: evidence for photoinhibition and photoprotection. Coral Reefs 18:99-105

Brown BE, Dunne RP, Warner ME, Ambarsari I, Fitt WK, Gibb SW, Cummings DG (2000) Damage and recovery of photosystem II during a manipulative field experiment on solar 
bleaching in the coral Goniastrea aspera. Mar Ecol Prog Ser 195:117-124

Demmig B, Bjorkman O (1987) Comparison of the effect of excessive light on chlorophyll fluorescence $(77 \mathrm{~K})$ and photon yield of $\mathrm{O}_{2}$ evolution in leaves of higher plants. Planta 171:171-184

Dennison WC, Barnes DJ (1988) Effect of water motion on coral photosynthesis and calcification. J Exp Mar Biol Ecol 115:67-77

Downs CA, Fauth JE, Halas JC, Dustan P, Bemiss J, Woodley CM (2002) Oxidative stress and seasonal coral bleaching. Free Radical Biol Med 33(4):533-543

Franklin LA, Levavasseur G, Osmond CB, Henley WJ, Ramus $\mathrm{J}$ (1992) Two components of onset and recovery during photoinhibition of Ulva rotundata. Planta 186:399-408

Glynn PW (1991) Coral reef bleaching in the 1980s and possible connections with global warming. Trends Ecol Evol 6:175-179

Glynn PW (1993) Coral bleaching: ecological perspectives. Coral Reefs 12:1-17

Glynn PW (1996) Coral reef bleaching: facts, hypothesis, and implications. Global Change Biol 2(6):495-509

Goreau TJ, Hayes RL (1994) Coral bleaching and ocean hotpots. Ambio 23(3):176-180

Goreau TJ, McClanahan T, Hayes R, Strong AE (2000) Conservation of coral reefs after 1998 global bleaching event. Conserv Biol 14(1):5-15

Hoegh-Guldberg O (1999) Climate change, coral bleaching and the future of the world's coral reefs. Mar Freshw Res 50:839-869

Hughes TP, Baird AH, Bellwood DR, Card M and 13 others (2003) Climate change, human impacts, and the resilience of coral reefs. Science 301:929-933

Jeffrey SW, Humphrey GF (1975) New spectrophotometric equations for determining chlorophylls a, b, c1, c2 in higher plants, algae and natural phytoplankton. Biochem Physiol Pflanz 167:191-194

Johannes RE, Wiebe WJ (1970) A method for determination of coral tissue biomass and composition. Liminol Oceanogr 21:540-647

Jokiel PL (1978) Effects of water motion on reef corals. J Exp Mar Biol Ecol 35:87-97

Jones RJ, Hoegh-Guldberg O (2001) Diurnal changes in the photochemical efficiency of the symbiotic dinoflagellates (Dinophyceae) of corals: photoprotection, photoinactivation and the relationship to coral bleaching. Plant Cell Environ 24:89-99

Jones RJ, Hoegh-Guldberg O, Larkum AWD, Schreiber U (1998) Temperature-induced bleaching of corals begins with impairment of the $\mathrm{CO}_{2}$ fixation mechanism in zooxanthellae. Plant Cell Environ 21:1219-1230

Kuffner IB (2001) Effects of ultraviolet radiation and water motion on the reef coral Porites compressa Dana: a flume experiment. Mar Biol 138:467-476

Kuffner IB (2002) Effects of ultraviolet radiation and water motion on the reef coral, Porites compressa Dana: a transplantation experiment. J Exp Mar Biol Ecol 270:147-169

Kushmaro A, Loya Y, Fine M, Rosenberg E (1996) Bacterial infection and coral bleaching. Nature 380:396

Lesser MP (1997) Oxidative stress causes coral bleaching during exposure to elevated temperatures. Coral Reefs 16: 187-192

Lesser MP, Weis VM, Patterson MR, Jokiel PL (1994) Effects of morphology and water motion on carbon delivery and productivity in the reef coral, Pocillopora damicornis (Linnaeus): diffusion barriers, inorganic carbon limitation, and biochemical plasticity. J Exp Mar Biol Ecol 178:153-179
Loya Y, Sakai K, Yamazato K, Nakano Y, Sambali H, van Woesik R (2001) Coral bleaching: the winners and the losers. Ecol Lett 4:122-131

Marsh JA (1970) Primary productivity of reef-building calcareous and red algae. Ecology 55:225-263

Mehler AH (1951) Studies on reactions of illuminated chloroplasts. I. Mechanism of the reduction of oxygen and other Hill reagents. Arch Biochem Biophys 33:65-77

Nakamura $T$, van Woesik R (2001) Water-flow rates and passive diffusion partially explain differential survival of corals during the 1998 bleaching event. Mar Ecol Prog Ser 212:301-304

Nakamura T, Yamasaki H, van Woesik R (2003) Water flow facilitates recovery from bleaching in the coral Stylophora pistillata. Mar Ecol Prog Ser 256:287-291

Osmond CB (1994) What is photoinhibition? Some insights from comparisons of shade and sun plants. In: Baker NR, Bowyer JR (eds) Photoinhibition of photosynthesis from molecular mechanisms to the field. Bios Scientific Publishers, Oxford, p 1-24

Patterson MR (1992) A mass-transfer explanation of metabolic scaling relations in some aquatic invertebrates and algae. Science 255:1421-1423

Patterson MR, Sebens KP (1989) Forced convection modulates gas exchange in cnidarians. Proc Natl Acad Sci USA 86: 8833-8836

Patterson MR, Sebens KP, Olson RR (1991) In situ measurements of flow effects on primary production and dark respiration in reef corals. Limnol Oceanogr 36 (5):936-948

Philipp E, Fabricius K (2003) Photophysiological stress in scleractinian corals in response to short-term sedimentation. J Exp Mar Biol Ecol 287:57-78

Richter M, Ruhle W, Wild A (1990) Studies on the mechanism of photosystem II photoinhibition. II. The involvement of toxic oxygen species. Photosynth Res 24:237-243

Schreiber U, Schliwa U, Bilger W (1986) Continuous recording of photochemical and non-photochmical chlorophyll fluorescence quenching with a new type of modulation fluorometer. Photosynth Res 10:51-62

Sebens KP, Helmuth B, Carrington E, Agius B (2003) Effects of water flow on growth and energetics of the scleractinian coral Agaricia tenuifolia in Belize. Coral Reefs 22: $35-47$

Sheppard CRC, Spalding M, Bradshaw C, Wilkinson S (2002) Erosion vs. recovery of coral reefs after 1998 El Nino: Chagos reefs, Indian Ocean. Ambio 31:40-48

Shick JM, Lesser MP, Jokiel PL (1996) Effects of ultraviolet radiation on corals and other coral reef organisms. Global Change Biol 2(6):527-545

Takahashi S, Nakamura T, Sakamizu M, van Woesik R, Yamasaki H (2004) Repair machinery of symbiotic photosynthesis as the primary target of heat stress for reefbuilding corals. Plant Cell Physiol 45(2):251-255

Thomas FIM, Atkinson ML (1997) Ammonium uptake by coral reefs: effects of water velocity and surface roughness on mass transfer. Limnol Oceanogr 42(1):81-88

Tjus SE, Scheller HV, Andersson B, Moller BL (2001) Active oxygen species produced during selective excitation of photosystem I is damaging not only to photosystem I, but also to photosystem II. Plant Physiol 125:2007-2015

Tortell PD, Rau GH, Morel FMM (2000) Inorganic carbon acquisition in coastal Pacific phytoplankton communities. Limnol Oceanogr 45:1495-1500

van Woesik R, DeVantier LM, Glazebrook JS (1995) Effects of cyclone 'Joy' on nearshore coral communities of the Great Barrier Reef. Mar Ecol Prog Ser 128:261-270

Warner ME, Fitt WK, Schmidt GW (1999) Damage to photo- 
system II in symbiotic dinoflagellates: a determinant of coral bleaching. Proc Natl Acad Sci USA 96:8007-8012

Warner ME, Chilcoat GC, McFarland FK, Fitt WK (2002) Seasonal fluctuations in the photosynthetic capacity of photosystem II in symbiotic dinoflagellates in the Caribbean reef-building coral Montastrea. Mar Biol 141:31-38

Editorial responsibility: Charles Birkeland (Contributing Editor), Honolulu, Hawaii, USA
Weis VM, Smith GJ, Muscatine L (1989) A ' $\mathrm{CO}_{2}$ supply' mechanism in zooxanthellate cnidarians: role of carbonic anhydrase. Mar Biol 100(2):195-202

Wilkinson CR (1999) Global and local threats to coral reef functioning and existence: review and predictions. Mar Freshw Res 50:867-878

Submitted: October 14, 2004; Accepted: March 31, 2005

Proofs received from author(s): September 5, 2005 